\title{
The potential environmental response to increasing ocean alkalinity for negative emissions
}

\author{
Sarah Gore $^{1}$ (D) Phil Renforth ${ }^{1} \cdot$ Rupert Perkins $^{1}$
}

Received: 29 August 2018 / Accepted: 31 October 2018/Published online: 23 November 2019

(C) The Author(s) 2018

\begin{abstract}
The negative emissions technology, artificial ocean alkalinization (AOA), aims to store atmospheric carbon dioxide $\left(\mathrm{CO}_{2}\right)$ in the ocean by increasing total alkalinity (TA). Calcium carbonate saturation state $\left(\Omega \mathrm{CaCO}_{3}\right)$ and $\mathrm{pH}$ would also increase meaning that AOA could alleviate sensitive regions and ecosystems from ocean acidification. However, AOA could raise $\mathrm{pH}$ and $\Omega \mathrm{CaCO}_{3}$ well above modern-day levels, and very little is known about the environmental and biological impact of this. After treating a red calcifying algae (Corallina spp.) to elevated TA seawater, carbonate production increased by $60 \%$ over a control. This has implication for carbon cycling in the past, but also constrains the environmental impact and efficiency of AOA. Carbonate production could reduce the efficiency of $\mathrm{CO}_{2}$ removal. Increasing TA, however, did not significantly influence Corallina spp. primary productivity, respiration, or photophysiology. These results show that AOA may not be intrinsically detrimental for Corallina spp. and that AOA has the potential to lessen the impacts of ocean acidification. However, the experiment tested a single species within a controlled environment to constrain a specific unknown, the rate change of calcification, and additional work is required to understand the impact of AOA on other organisms, whole ecosystems, and the global carbon cycle.
\end{abstract}

Keywords Ocean alkalinity $\cdot$ Corallina spp. $\cdot$ Calcification $\cdot$ Carbon dioxide removal $\cdot$ Artificial ocean alkalinization

\section{Introduction}

To meet the Paris Agreement (United Nations Framework Convention on Climate Change 2015), which aims to limit global temperature change to below $2{ }^{\circ} \mathrm{C}$, negative emission

Sarah Gore

goresj@ cardiff.ac.uk

1 School Earth and Ocean Sciences, Cardiff University, Cardiff, UK 
technologies (NETs also known as "carbon dioxide removal") may be needed in addition to severely reduced greenhouse gas emissions. One possible NET is artificial ocean alkalinization (AOA) which stores atmospheric carbon dioxide $\left(\mathrm{CO}_{2}\right)$ in the ocean as bicarbonate ions $\left(\mathrm{HCO}_{3}{ }^{-}\right)$by increasing ocean total alkalinity (TA) (Kheshgi 1995). There are several proposals for increasing ocean TA. These include adding naturally occurring and abundant alkaline minerals, such as olivine $\left(\left[\mathrm{Mg}^{+2}, \mathrm{Fe}^{+2}\right]_{2} \mathrm{SiO}_{4}\right)$ (Köhler et al. 2010), limestone $\left(\mathrm{CaCO}_{3}\right)$ (Harvey 2008), or basalt (Beerling et al. 2018; Rigopoulos et al. 2017) to the ocean or land surfaces (Hartmann et al. 2013). Other proposals include accelerated limestone weathering (Rau and Caldeira 1999), electrochemical acceleration of silicate weathering (House et al. 2007; Rau et al. 2018), and the addition of lime $(\mathrm{CaO})$ or quick lime $\left(\mathrm{Ca}(\mathrm{OH})_{2}\right)$ to the surface ocean (Kheshgi 1995; Renforth et al. 2013). The overall objective of these proposals is to accelerate the natural weathering reactions which would otherwise take tens to hundreds of thousands of years to remove atmospheric $\mathrm{CO}_{2}$ by increasing ocean TA (Archer 2005; Lord et al. 2016).

An additional benefit of AOA is that it could alleviate regions from ocean acidification. Ocean acidification is the recent, and potential future, decrease in ocean $\mathrm{pH}$ and calcium carbonate saturation state $\left(\Omega_{\mathrm{CaCO} 3}\right)$ caused by rising atmospheric $\mathrm{CO}_{2}$. Ocean acidification has already influenced the marine environment by making it more difficult for some marine calcifiers to produce their calcium carbonate $\left(\mathrm{CaCO}_{3}\right)$ shells (Doney et al. 2009). Artificially increasing ocean TA and the resulting increase in $\Omega_{\mathrm{CaCO} 3}$ would have the opposite effect, making it easier to calcify (Feng et al. 2017). Therefore, AOA could potentially allow ecosystems previously affected by reduced calcification (due to ocean acidification) to return to pre-industrial calcification values (Albright et al. 2016).

Although increasing ocean TA could be a way of alleviating ocean acidification, it could also increase ocean $\mathrm{pH}$ and $\Omega_{\mathrm{CaCO} 3}$ well above pre-industrial values, particularly in the regions where the alkaline minerals were added (Renforth and Henderson 2017; Feng et al. 2017) (Fig. 1). Therefore, if AOA was deployed, the ecosystems located close to where TA was increased could face significant changes. Most studies to date focus on what effect a decrease in $\mathrm{pH}$ and $\Omega_{\mathrm{CaCO} 3}$ will have on marine ecosystems (ocean acidification studies). There are a few studies, however, that have investigated the response following an increase in TA and $\Omega_{\mathrm{CaCO} 3}$. Cripps et al. (2013) found that increased TA (raising $\mathrm{pH}$ up to 8.8 and $\Omega_{\mathrm{CaCO} 3}$ up to 12.6) caused abnormal acid-base balance and increased haemolymph $\mathrm{pH}$ in the marine calcifier Carcinus maenas. Albright et al. (2016) investigated the response of a coral reef flat to increased TA (raising $\mathrm{pH}$ to 8.3 and aragonite $\Omega_{\mathrm{CaCO} 3}$ to $\sim 6$ ) and found that net community calcification increased. Further, a recent study by Gim et al. (2018) studied the ecotoxicological effects of increased $\mathrm{HCO}_{3}{ }^{-}$on various marine organisms, including both marine calcifiers and non-calcifiers. Their results showed a species-specific response to elevated $\mathrm{HCO}_{3}{ }^{-}$, suggesting that the ecosystem's response to increased TA will not be easy to predict. There is still very little information on what impact TA addition will have on ecosystems and how marine organisms, including marine calcifiers, will respond to a large increase in TA.

Coastal environments are a favourable site for alkalinity addition by providing geochemical and environmental benefits over open ocean AOA (Meysman and Montserrat 2017; Schuiling and de Boer 2010). An important feature of coastal ecosystems across the globe is red calcifying macroalgae (Corallinales; Akioka et al. 1999). Therefore, a global AOA scheme will likely impact both Corallinales and 


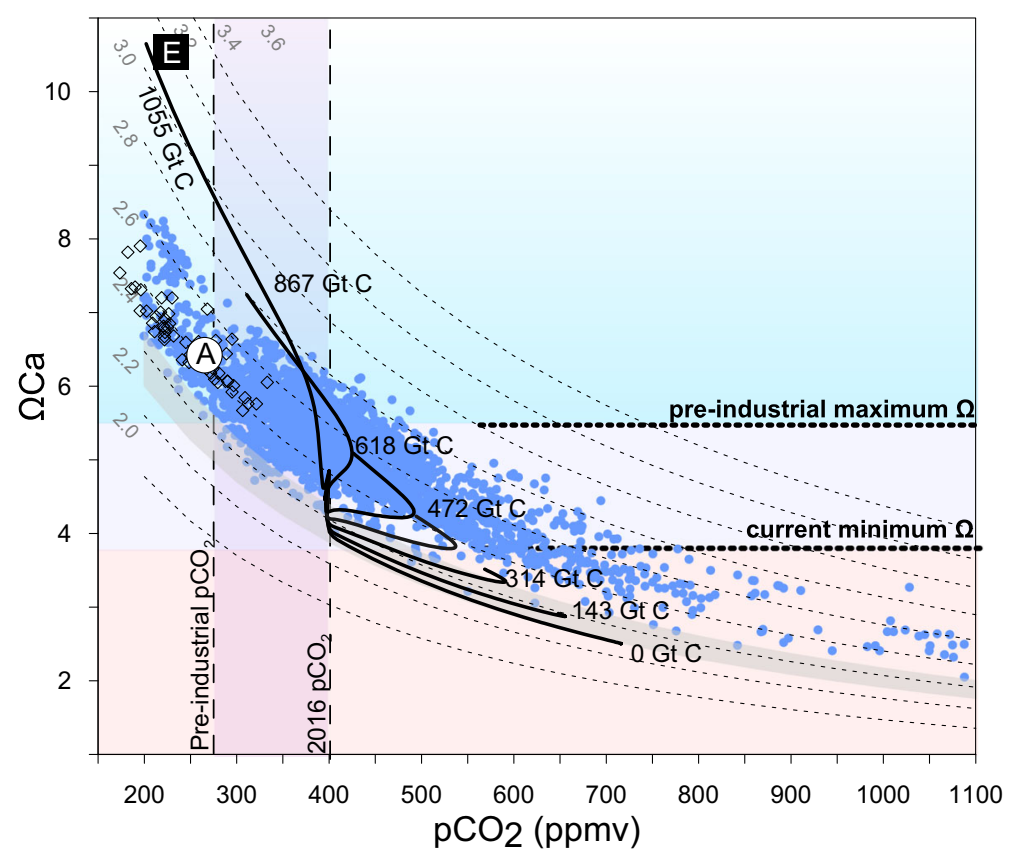

Fig. 1 Results from a three-box model mimicking significant features of the ocean carbon system (http://www. noc.soton.ac.uk/jmodels/; Chuck et al. (2005) reported in Renforth and Henderson 2017) showing the relationship between calcite saturation state $\left(\Omega_{\mathrm{Ca}}\right)$ and $\mathrm{pCO}_{2}$ and associated ocean carbon storage (GtC) for various total alkalinity (TA) addition scenarios (RCP 6.0 business as usual and 0.5, 1, 1.5, 2, 3, 4 x TA addition) after 120 years. The contours represent average surface ocean (0-100 m depth) TA in $\mathrm{mEq} \mathrm{L}{ }^{-1}$ at $16^{\circ} \mathrm{C}$ and $35 \%$ salinity. The black square shows the mean $\Omega_{\mathrm{Ca}}$ and $\mathrm{pCO}_{2}$ for the elevated alkalinity treatment $(\mathrm{E})$, and the white circle shows the mean $\Omega_{\mathrm{Ca}}$ and $\mathrm{pCO}_{2}$ for the ambient alkalinity treatment (A) of this experiment. The blue circles show average $\Omega \mathrm{Ca}$ and $\mathrm{pCO}_{2}$ of 23 coral reef locations (data from Cyronak et al. 2018). Empty diamonds show ocean $\Omega_{\mathrm{Ca}}$ and $\mathrm{pCO}_{2}$ reconstructed from Hönisch et al. (2009) for the past $2 \mathrm{Ma}$

coastal ecosystems. Corallinales are some of the most prolific producers of $\mathrm{CaCO}_{3}$, particularly in temperate shallow coastal waters (Martin et al. 2007) producing highmagnesium calcite (HMC) (Basso 2012). $\mathrm{HMC}$ is the most soluble form of $\mathrm{CaCO}_{3}$ in the marine environment suggesting that HMC producers such as the Corallinales could be particularly vulnerable to ocean acidification (Andersson et al. 2008; Martin and Gattuso 2009; Hofmann et al. 2012a; Hofmann et al. 2012b; Williamson et al. 2014). However, Corallinales also grow in dynamic environments and so are used to relatively large daily and seasonal changes in carbonate chemistry which could promote resilience to changes caused by ocean acidification (Egilsdottir et al. 2013; Noisette et al. 2013). These variable results indicate that Corallinales' sensitivity to ocean acidification is complex and suggests that predicting Corallinales' sensitivity to AOA could be equally challenging.

This paper aims to investigate the potential environmental and biological responses to AOA by presenting results from an ex-situ experiment that tests how red calcifying algae, Corallina spp. (of the family Corallinales) responds to an increase in TA. Corallina spp. physiology (calcification, primary productivity, respiration, and photophysiology) was investigated for 3 weeks in an ex-situ experimental set-up. 


\section{Methods}

\subsection{Sample collection}

Corallina samples were collected from Dunraven Bay, a rocky shore near Southerndown, South Wales $\left(51^{\circ} 44.65^{\prime} \mathrm{N}, 03^{\circ} 60.73^{\prime} \mathrm{W}\right)$ during February 2018 . The samples were carefully removed from their substrate making sure to obtain their encrusting base. Dunraven Bay consists of a heavily pitted limestone wave cut platform with rock pools. The rock pool temperature, $\mathrm{pH}$, and salinity were measured on site using a temperature and $\mathrm{pH}$ combination electrode and refractometer. Photochemically active radiation (PAR) was measured at the water depth at which the Corallina was growing using a 4-pi LI-COR cosine-corrected quantum sensor respectively. The chemical and physical properties of the rock pool water are summarised in Table 1. Corallina samples were randomly selected from the rock pools found in the intertidal region of Dunraven Bay.

Two common species of red calcifying macroalgae (Corallinales) found in the UK are Corallina officinalis and Corallina elongata (Williamson et al. 2014). Frond morphology of the samples collected closely matched that of $C$. officinalis; therefore, the samples collected were decided to be most likely $C$. officinalis. However, morphological characters alone are often not sufficient enough to identify the Corallinales to subfamily taxonomic levels (Bailey and Chapman 1998), and because no formal identification was made (e.g., using DNA comparisons), the samples will be referred to as simply Corallina spp. herein.

The Corallina spp. samples and $\sim 100 \mathrm{~L}$ of site water were transported back to Cardiff University. The site water was filtered using the methodology of Walsh et al. (2009) then stored in a flow-through chamber within a greenhouse. Twelve undamaged Corallina spp. samples that were visually free from epiphytes were chosen. Each sample had a similar number of fronds (8-10) and frond length $(4-6 \mathrm{~cm})$ and weight $\sim 1 \mathrm{~g}$ (wet). The 12 Corallina spp. samples were submerged in 1-L glass chambers containing $400 \mathrm{~mL}$ of site water. Two blank 1-L bottles containing $400 \mathrm{~mL}$ of original seawater but no Corallina spp. sample were also prepared. These control bottles were used to account for any differences in carbonate chemistry not caused by the Corallina spp. samples.

\subsection{Experimental set-up}

The experimental set-up consisted of two TA treatments, an elevated TA treatment (elevated alkalinity) and an ambient TA treatment (ambient alkalinity). Every 48 h, each glass chamber was refreshed with $400 \mathrm{~mL}$ of filtered site water from the flow-through chamber. For the elevated alkalinity treatment, TA was increased by $\sim 1000 \mu \mathrm{Eq} \mathrm{L}-1$ by adding $0.5 \mathrm{~mol} \mathrm{~L}^{-1}$ $\mathrm{Na}_{2} \mathrm{CO}_{3}$ and bubbling with ambient air for $2 \mathrm{~h}$, to ensure that $\Omega_{\mathrm{CaCO} 3}$ did not exceed 10 . This was carried out before being added to the Corallina spp. chambers. For the ambient alkalinity

Table 1 Average \pm standard error chemical and physical properties of Dunraven Bay rock pool water

\begin{tabular}{ll}
\hline Parameter & Value during collection \\
\hline Salinity & 30 \\
Temperature $\left({ }^{\circ} \mathrm{C}\right)$ & $6.5 \pm 0.05$ \\
Photochemically active radiation $(\mathrm{PAR})\left(\mu \mathrm{mol}\right.$ photons $\left.\mathrm{m}^{-2}\right)$ & $150-740$ \\
$\mathrm{pH}$ & $8.17 \pm 0.05$ \\
\hline
\end{tabular}


treatment, TA was unmodified but was still bubbled with ambient air for $2 \mathrm{~h}$ to allow for consistency between the treatments. The carbonate chemistry for both the ambient and elevated alkalinity treatments is summarised in Table 2 and Fig. 2. For the first 7 days, four out of the 12 glass chambers containing Corallina spp. samples were refreshed with elevated TA (elevated 1) water and eight were refreshed with ambient TA water (ambient). On day 8 (and for the remainder of the experiment), four of the ambient TA Corallina spp. samples were then subjected to elevated TA water instead (elevated 2). Of the two blank chambers with no Corallina spp. samples, one was refreshed with elevated alkalinity water and the other with ambient alkalinity water every $48 \mathrm{~h}$. Each glass chamber was placed in a $10{ }^{\circ} \mathrm{C}$ temperaturecontrolled fridge. Irradiance above the glass chambers was adjusted to $200 \mu \mathrm{mol}$ photons $\mathrm{m}^{-2} \mathrm{~s}^{-1}$. The light source consisted of $39 \mathrm{~W}$ LED tubes (JBL Solar Ultra Marin Day, JBL Aquaria, Nelson, New Zealand) placed above the aquaria, and the photoperiod was adjusted to $12 \mathrm{~h} / 12 \mathrm{~h}$ light/dark period. The samples were kept alive for 3 weeks.

\subsection{Net calcification, primary productivity, and respiration}

Before refreshing the seawater, $100 \mathrm{~mL}$ of the solution from the glass chambers was collected and filtered through $0.22 \mu \mathrm{m}$ filters (Minisart syringe filters, Sartorius, Germany). One hundred millilitres of both elevated and ambient alkalinity treatment seawater was also collected. The $\mathrm{pH}$ of each water sample was measured using a $\mathrm{pH}$ electrode (Mettler Toledo ${ }^{\mathrm{TM}}$, U.K.) calibrated with TRIS and AMPD seawater buffer solutions according to Dickson et al. (2007).

Gran titration (907 Titrando, Metrohm tiamo ${ }^{\mathrm{TM}}$, Switzerland), used to measure TA, was calibrated using reference measurements of carefully prepared $\mathrm{Na}_{2} \mathrm{CO}_{3}$ standards $(0.5,1.0$, and $1.25 \mathrm{mmol} \mathrm{L}^{-1}$ ) in $0.7 \mathrm{~mol} \mathrm{~L}^{-1} \mathrm{NaCl}$ background medium according to Dickson et al. (2007). Accuracy and precision were determined by 6 titrations of an alkalinity standard (Batch 126) supplied by the University of California San Diego. The absolute error of the TA measurements was $\pm 20 \mu \mathrm{Eq} \mathrm{L}{ }^{-1}$. Afterward, $\mathrm{pH}$, TA, water temperature, and salinity were used to determine the other carbonate chemistry parameters (DIC, $\mathrm{pCO} 2, \mathrm{HCO}_{3}{ }^{-}$, and $\mathrm{CO}_{3}{ }^{2-}$, and the saturation states of aragonite $[\Omega \mathrm{Ar}]$ and calcite $[\Omega \mathrm{Ca}]$ ) by inputting the values into $\mathrm{CO} 2 \mathrm{SYS}$ v2.1 (Pierrot et al. 2006). CO2SYS was run using the constants of Mehrbach et al. (1973) refitted by Dickson and Millero (1987).

The net calcification rate $\left(\mathrm{NCR}=\mu \mathrm{mol} \mathrm{CaCO}_{3} \mathrm{gDW}^{-1} \mathrm{~h}^{-1}\right)$ was calculated from the change in TA before and after refreshing with the ambient/elevated alkalinity water (Eq. 1).

$$
\mathrm{NCR}=\frac{\Delta \mathrm{TA} * v}{2 * g D W * h}
$$

where $v$ is the volume of water in the glass chamber $(400 \mathrm{~mL}), g D W$ is the dry weight of the Corallina spp. samples in grams, and $h^{-1}$ is the time elapsed in hours $(48 \mathrm{~h})$. The amount of $\mathrm{CaCO}_{3}$ precipitated $\left(\mu \mathrm{mol} \mathrm{CaCO}_{3}\right.$ ) was estimated using the alkalinity anomaly technique (Smith and Key 1975; Chisholm and Gattuso 1991) which assumes a decrease in TA by $2 \mu \mathrm{Eq}$ equals $1 \mu \mathrm{mol}$ of $\mathrm{CaCO}_{3}$ precipitated. Nitrogen uptake during primary productivity can also influence TA. However, the change in TA due to nitrogen uptake was calculated using calculation 39 in Wolf-Gladrow et al. (2007) and was found to be $<4 \%$ of the overall TA change, therefore, was ignored. The blank chambers were used to account for any changes in TA not produced by Corallina spp. 


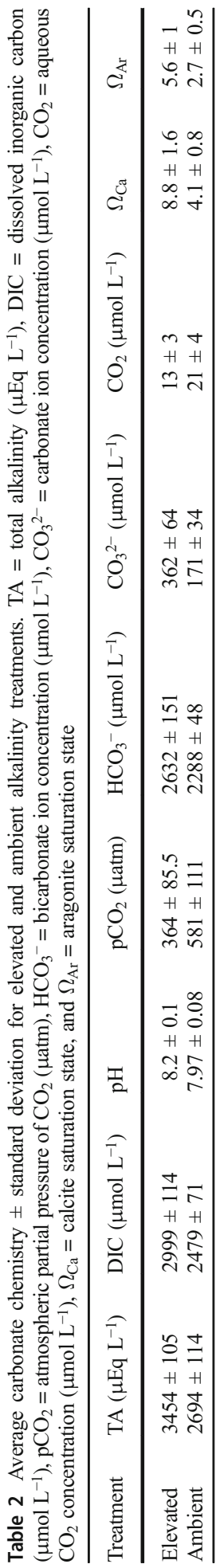


Calcification rates (CRs) for light and dark periods were also determined during week 1 and week 2. The 12 Corallina spp. chambers and two blank chambers were refreshed with $200 \mathrm{~mL}$ of elevated/ambient alkalinity water then left in either in light or dark conditions for $6 \mathrm{~h}$. The $\mathrm{pH}$ was measured at the start of the $6 \mathrm{~h}$ (after being the water had been bubbled with ambient air) and again at the end of the $6 \mathrm{~h}$. The $\mathrm{pH}$ and TA measured at the start and at the end of the 6-h experiment were then used to calculate how DIC changed over the course of the 6 hours. DIC was calculated using CO2SYS v2.1 (Pierrot et al. 2006). The change in DIC and the light and dark CRs were then used to estimate net primary productivity (NPP =

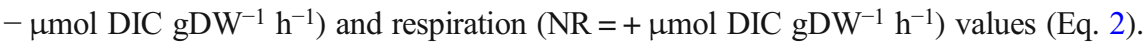

$$
\mathrm{NPP} \text { or } \mathrm{NR}=\frac{\Delta \mathrm{DIC}^{*} v}{g D W^{*} h}-C R(\text { dark }) /(\text { light })
$$

where $C R$ (dark) is the $\mathrm{CR}$ calculated from the change in TA in dark conditions and $C R$ (light) is the CR calculated from the change in TA in light conditions. Because the light and dark experiments occurred in an open-system, there may have been changes in $\mathrm{pH}$ caused by $\mathrm{CO}_{2}$ gas-solution transfer. The blank chambers were used to account for any changes in TA and $\mathrm{pH}$ not produced by Corallina spp. and used to correct light/dark CR, NPP, and NR for these changes.

The $\mathrm{CaCO}_{3}$ and organic carbon content of the Corallina spp. samples were also measured. First, the organic carbon $\left(\mathrm{C}_{\text {org }}\right)$ content of the samples was measured by the loss in mass of the samples after combustion at $500{ }^{\circ} \mathrm{C}$ for $6 \mathrm{~h}$. Then, the $\mathrm{CaCO}_{3}$ content of the remaining ash was estimated using a FOGII Digital Calcimeter (BD Inventions P.C., Greece). Primary productivity rates $\left(\mathrm{mg} \mathrm{C}_{\text {org }} \mathrm{gDW}^{-1} \mathrm{~h}^{-1}\right.$ ) were calculated assuming the ratio of $\mathrm{CaCO}_{3}$ to $\mathrm{C}_{\text {org }}$ content of the Corallina spp. did not change throughout the experiment and were equivalent to the measured cumulative alkalinity change.

The Corallina spp. dry weight $(g D W)$ used in Eqs. 1 and 2 is an average of the initial and end dry weight of the Corallina spp. Following the experiment, the Corallina spp. samples were dried at $100{ }^{\circ} \mathrm{C}$ for $24 \mathrm{~h}$ to obtain the dry weight. The dry weight of Corallina spp. at the beginning of the experiment was estimated using the Corallina spp. dry weight at the end of the experiment minus the $\mathrm{C}_{\text {org }}$ produced (estimated from the combustion data) and cumulative $\mathrm{CaCO}_{3}$ produced (in grams).

\subsection{Photophysiology}

The photophysiology of the Corallina spp. samples was determined using PAM fluorometry. Rapid light curves (RLCs) were performed using a Walz Water-PAM fluorometer, after the chambers were refreshed with new site water, following the methodology of Perkins et al. (2006). Four replicate light curves were performed for both the elevated and ambient alkalinity treatments. RLC measurements were made on the tips of the upper-facing Corallina spp. fronds to avoid sampling potentially self-shaded frond regions and to minimise differential photoacclimation (i.e., due to differences in light history between upper and lower surfaces of fronds). RLCs were preformed after each Corallina spp. sample was dark-adapted for 5 min.

Analysis of RLC was done using R v.3.4.1 (R Core Team 2013) and followed that described by Perkins et al. (2006) with curve fitting following the iterative solution of Eilers and Peeters (1988) to determine coefficients $a, b$, and $c$ and hence calculation of light curve parameters of relative maximum electron transport rate $\left(\mathrm{rETR}_{\max }\right)$, coefficient of light use 
efficiency $(\alpha)$, and light saturation coefficient $\left(E_{k}\right)$. The shape of the RLC $\left(\mathrm{rETR}_{\max }, \alpha, E_{k}\right)$ gives an indication to how efficient photosynthesis is. The first part of the RLC (the rise of the curve in the light limiting region) is proportional to the efficiency of light capture (effective quantum yield or $\alpha$; Schreiber 2004), where the RLC peaks is used to determine the maximum photosynthetic capacity $\left(\mathrm{rETR}_{\max }\right.$; Schreiber 2004). The interception of $\mathrm{rETR}_{\max }$ and $\alpha$ determines the minimum saturating irradiance $\left(E_{k}\right.$; Sakshaug et al. 1997). $E_{k}$ is related to how much light energy is either used for photosynthesis (photochemical quenching) or is emitted as fluorescence or converted to heat (non-photochemical quenching). The higher the $E_{k}$ value, the more energy is used for photochemical quenching (Henley 1993). In the most simple terms, an increase in $\mathrm{rETR}_{\max }, \alpha$, and $E_{k}$ suggests more efficient photosynthesis and a decrease in these values could suggest the Corallina spp. is becoming stressed.

The Genty parameter $\left(F_{v} / F_{m}\right)$ which is the approximate maximum light use efficiency in the dark-adapted state (Genty et al. 1989) and therefore gives an overall indication of the health of the Corallina spp. samples. $F_{v} / F_{m}$ was calculated using R v.3.4.1 (R Core Team 2013). The Genty parameter is defined as:

$$
F_{v} / F_{m}=\left(F_{m}-F_{o}\right) / F_{m}
$$

where $F_{m}$ is the maximum yield, and $F_{o}$ is the minimum fluorescence yield in the dark-adapted state.

\subsection{Data analysis}

All figures were produced using either Grapher ${ }^{\mathrm{TM}} 13$ (Golden Software, LLC) or MATLAB R2018b (MathWorks Inc., 2018). Where averages are given, the error is quoted as standard error ( \pm S.E.) in the text, figures, or tables unless otherwise stated. All statistical analyses were performed using R v.3.4.1 (R Core Team 2013). Prior to all analyses, normality of data was tested using the Shapiro-Wilk test and examination of frequency histograms. Differences in parameters (NCR, NPP, NP, $\operatorname{rETR}_{\max }, \alpha, E_{k}$, and $F_{v} / F_{m}$ ) between the two alkalinity treatments were examined using Student's $t$ test. Where data were not normally distributed, a MannWhitney $U$ test was preformed instead. Differences were deemed significant if $p<0.05$. Linear regressions were preformed to determine any significant relationships between $\mathrm{NCR}, \mathrm{rETR}_{\max }$, $\alpha, E_{k}$, and $F_{v} / F_{m}$ and TA, $\mathrm{pH}$, temperature, and irradiance (PAR). Additional linear regressions models were run to determine any significant relationship between NCR and photophysiology $\left(\mathrm{rETR}_{\max }, \alpha, E_{k}\right.$, and $\left.F_{v} / F_{m}\right)$.

\section{Results}

\subsection{Calcification}

Throughout the experiment, $\mathrm{TA}, \mathrm{pH}$, and $\Omega \mathrm{Ca}$ were consistently higher in the elevated alkalinity treatment compared to the ambient alkalinity treatment (Fig. 2). Corallina spp. NCR was significantly higher $(\sim 60 \%)$ in the elevated alkalinity treatment compared to that in the ambient alkalinity treatment throughout the study period (Table 3, Fig. 3a). Average Corallina spp. NCR for elevated alkalinity was $8.47 \pm 0.85 \mu \mathrm{mol} \mathrm{CaCO}_{3} \mathrm{gDW}^{-1} \mathrm{~h}^{-1}$ compared to $5.34 \pm 0.61 \mu \mathrm{mol} \mathrm{CaCO}_{3} \mathrm{gDW}^{-1} \mathrm{~h}^{-1}$ for ambient alkalinity. The $\mathrm{CaCO}_{3}$ content 

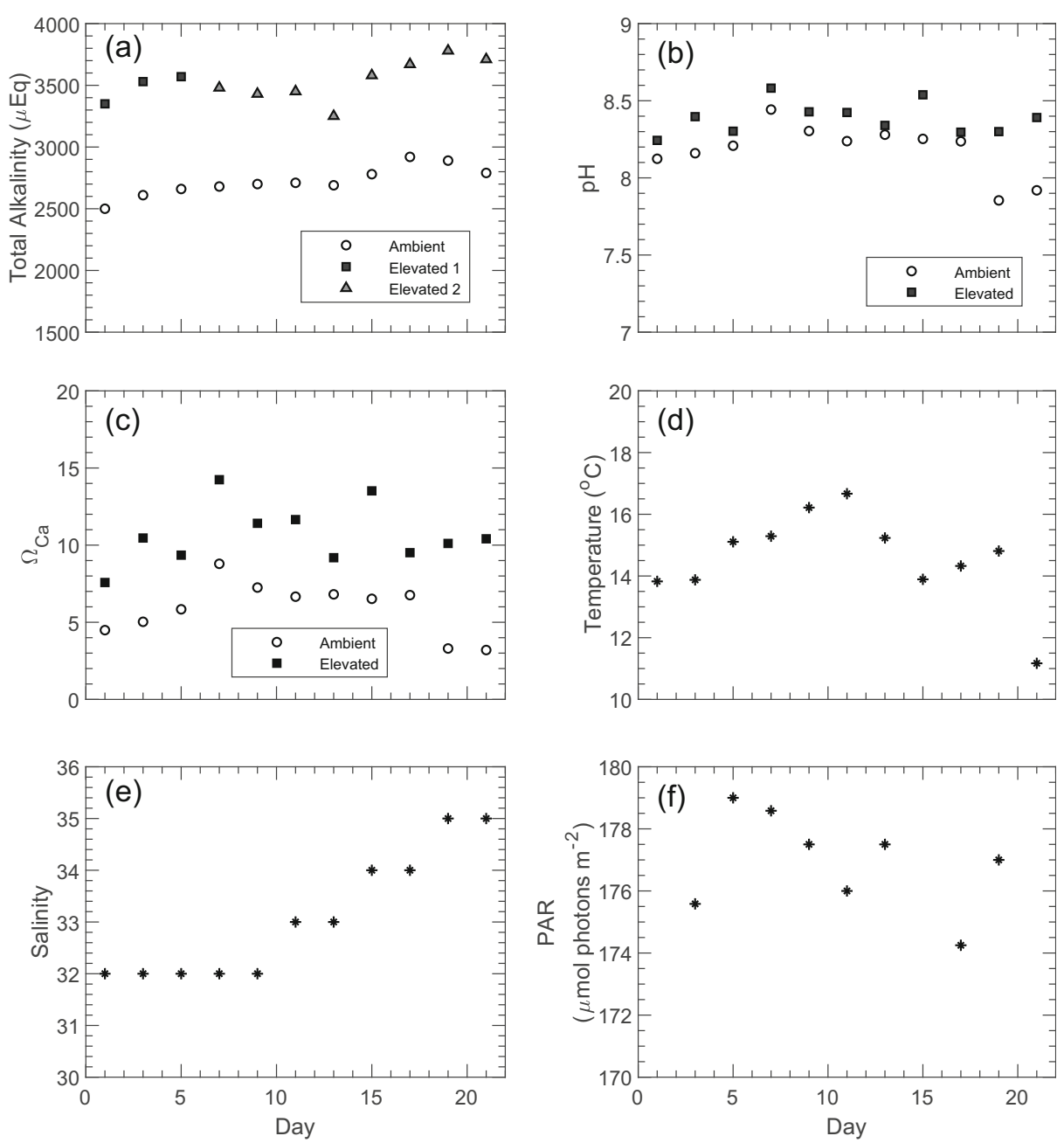

Fig. 2 Physical and carbonate chemistry properties of the experimental set-up. a Total Alkalinity $\left(\mu \mathrm{Eq} \mathrm{L} \mathrm{L}^{-1}\right), \mathbf{b}$ $\mathrm{pH}$, c Calcite saturation state $\left(\Omega_{\mathrm{Ca}}\right), \mathbf{d}$ Temperature $\left({ }^{\circ} \mathrm{C}\right)$, e Salinity, and $\mathbf{f}$ Photochemically active radiation (PAR; $\mu \mathrm{mol}$ photons $\mathrm{m}^{-2}$ ). Carbonate chemistry properties are divided into ambient alkalinity treatment (ambient; empty circles) and elevated alkalinity treatment which is further divided into elevated 1 (elevated 1; black squares) and elevated 2 (elevated 2; grey triangles). For elevated 1, total alkalinity was increased on day 1 and for elevated 2 , total alkalinity was increased on day 8

measured at the end of the experiment was $\sim 3 \%$ higher for the Corallina spp. samples exposed to the elevated alkalinity treatments compared to the samples exposed to the ambient alkalinity treatment (Table 4). There was a significant positive linear relationship between NCR and TA, NCR and $\mathrm{pH}$, and NCR and PAR (Table 5) with the strongest relationship between NCR and TA $\left(R^{2}=0.3254, p<0.001\right)$.

Corallina spp. NCRs were significantly higher $(p<0.05)$ in the elevated 2 alkalinity treatment, where TA was increased after day 8, compared to the elevated 1 alkalinity treatment, where TA was increased straight away (Fig. 3a). Average Corallina spp. NCR for the elevated 1 alkalinity treatment was $8.05 \pm 0.80 \mu$ mol $\mathrm{CaCO}_{3} \mathrm{gDW}^{-1} \mathrm{~h}^{-1}$ and for the elevated 2 
Table 3 Average Corallina spp. physiology values $\left(\mathrm{NCR}\left(\mu \mathrm{mol} \mathrm{CaCO}_{3} \mathrm{gDW}^{-1} \mathrm{~h}^{-1}\right)\right.$, LCR $=$ light $\mathrm{CR}$ $\left(\mu \mathrm{mol} \mathrm{CaCO}_{3} \mathrm{gDW}^{-1} \mathrm{~h}^{-1}\right), \mathrm{DCR}=$ dark $\mathrm{CR}\left(\mu \mathrm{mol} \mathrm{CaCO}_{3} \mathrm{gDW}^{-1} \mathrm{~h}^{-1}\right), \mathrm{NPP}\left(\mu \mathrm{mol} \mathrm{DIC} \mathrm{gDW}^{-1} \mathrm{~h}^{-1}\right), \mathrm{NR}^{-}$ $\left(\mu \mathrm{mol} \mathrm{DIC} \mathrm{gDW}^{-1} \mathrm{~h}^{-1}\right), \mathrm{rETR}_{\max }, F_{v} / F_{m}, \alpha$, and $E_{k}$. Significant codes: $* * * p<0.001, \mathrm{~ns}=$ not significant

\begin{tabular}{|c|c|c|c|c|c|c|c|}
\hline \multirow[t]{2}{*}{ Parameter } & \multicolumn{2}{|c|}{ No. of samples } & \multicolumn{2}{|c|}{ Average value } & \multicolumn{2}{|c|}{ Standard error } & \multirow[t]{2}{*}{ Significance } \\
\hline & Elevated & Ambient & Elevated & Ambient & Elevated & Ambient & \\
\hline NCR & 60 & 47 & 8.47 & 5.34 & 0.85 & 0.61 & $* * *$ \\
\hline CR (light) & 8 & 8 & 12.43 & 8.83 & 1.02 & 0.64 & ns \\
\hline CR (dark) & 8 & 8 & 2.29 & -0.01 & 0.34 & 0.36 & ns \\
\hline NPP & 8 & 8 & -11.86 & -5.87 & 1.47 & 0.79 & ns \\
\hline NR & 8 & 8 & 0.645 & -0.045 & 0.29 & 0.15 & ns \\
\hline $\mathrm{rETR}_{\max }$ & 47 & 45 & 35 & 36 & 2 & 2 & ns \\
\hline$F_{v} / F_{m}$ & 47 & 45 & 0.68 & 0.69 & 0.02 & 0.02 & ns \\
\hline$\alpha$ & 47 & 45 & 0.13 & 0.13 & 0.01 & 0.01 & ns \\
\hline$E_{k}$ & 47 & 45 & 287 & 271 & 20 & 12 & ns \\
\hline
\end{tabular}

alkalinity treatment was $9.34 \pm 0.84 \mu \mathrm{mol} \mathrm{CaCO}_{3} \mathrm{gDW}^{-1} \mathrm{~h}^{-1}$. There was substantial temporal variation in Corallina spp. NCR for the ambient alkalinity treatment throughout the experiment. There was an initial increase of $74 \%$ from day 1 to 16 but then decreased back to the starting values by day 21 , compared to a $40 \%$ increase in Corallina spp. NCR in the elevated 1 alkalinity treatment during the same time period (Fig. 3a).

Corallina spp. had higher rates of both light CR and dark CR when exposed to elevated alkalinity compared to the ambient alkalinity treatment. On average, the light CR was $12.43 \pm 1.02 \mu \mathrm{mol} \mathrm{CaCO}_{3} \mathrm{gDW}^{-1} \mathrm{~h}^{-1}$, which was $40 \%$ higher than the ambient alkalinity treatment $\left(8.83 \pm 0.64 \mu \mathrm{mol} \mathrm{CaCO}_{3} \mathrm{gDW}^{-1} \mathrm{~h}^{-1}\right.$; Table 3). Corallina spp. dark $\mathrm{CR}$ also substantially increased when exposed to the elevated alkalinity treatment compared to the ambient alkalinity treatment $\left(2.29 \pm 0.34 \mu \mathrm{mol} \mathrm{CaCO}_{3} \mathrm{gDW}^{-1} \mathrm{~h}^{-1}\right.$ compared to -0.01 $\pm 0.36 \mu \mathrm{mol} \mathrm{CaCO}_{3} \mathrm{gDW}^{-1} \mathrm{~h}^{-1}$ respectively; Table 3). There was no significant difference between the alkalinity treatments for both the ambient and elevated alkalinity treatments (Table 3). The rates for Corallina spp. light and dark calcification increased from week 1 to week 2 (Fig. 3b).

\subsection{Primary productivity (NPP) and respiration (NR)}

After Corallina spp. were exposed to light conditions for $6 \mathrm{~h}$, there was a substantial increase in $\mathrm{pH}$ for both the elevated and ambient alkalinity treatment water (increase of 0.57 and 0.67 respectively). This change in $\mathrm{pH}$ and in TA was used to estimate the rate of Corallina spp. NPP, which almost doubled when exposed to elevated alkalinity compared to the ambient alkalinity treatment. On average, the elevated alkalinity treatment NPP rate was -11.86 $\pm 1.47 \mu \mathrm{mol}$ DIC $\mathrm{gDW}^{-1} \mathrm{~h}^{-1}$ and the ambient alkalinity treatment NPP rate was -5.87 $\pm 0.79 \mu \mathrm{mol}$ DIC $\mathrm{gDW}^{-1} \mathrm{~h}^{-1}$. The negative values indicate that $\mathrm{CO}_{2}$ was used up in photosynthesis.

After the Corallina spp. were exposed to dark conditions for $6 \mathrm{~h}$, there was a decrease in $\mathrm{pH}$ for both the elevated and ambient alkalinity treatment water (decrease of 0.30 and 0.19 respectively). Both the elevated and ambient alkalinity treatments resulted in very low rates for NR $\left(-0.29 \pm 0.39 \mu \mathrm{mol} \mathrm{DIC}_{\mathrm{gDW}}^{-1} \mathrm{~h}^{-1}\right.$ and 0.58 $\pm 0.20 \mu \mathrm{mol}$ DIC $\mathrm{gDW}^{-1} \mathrm{~h}^{-1}$ respectively). 

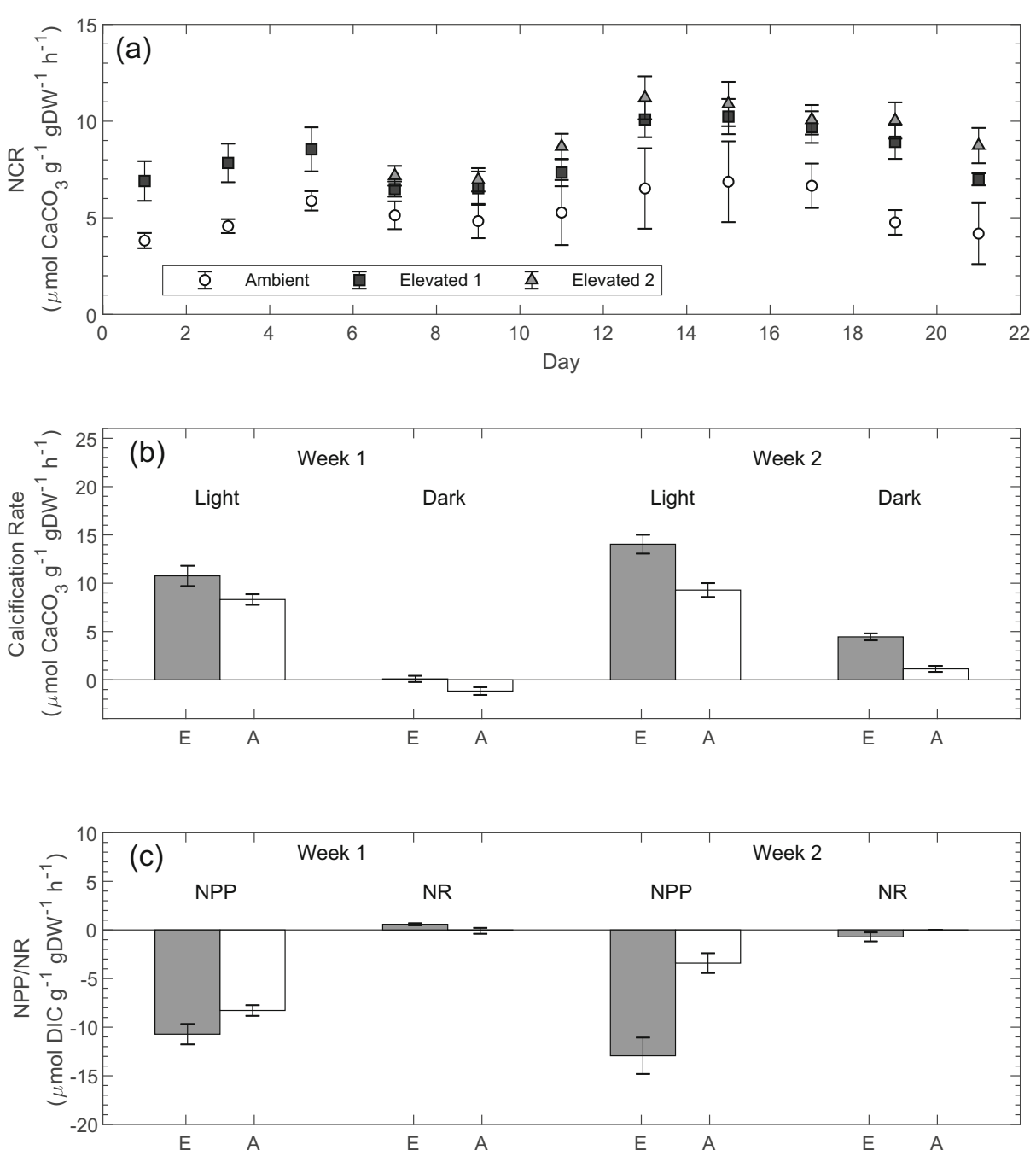

Fig. 3 Average Corallina spp. a net calcification rate (NCR; $\mu \mathrm{mol} \mathrm{CaCO}_{3} \mathrm{gDW}^{-1} \mathrm{~h}^{-1}$ ), b light and dark Corallina spp. calcification rates $\left(\mu \mathrm{mol} \mathrm{CaCO}_{3} \mathrm{gDW}^{-1} \mathrm{~h}^{-1}\right)$, and c Corallina net primary productivity and net respiration (NPP/NR $\mu \mathrm{mol}$ DIC $\mathrm{gDW}^{-1} \mathrm{~h}^{-1}$ ) for the elevated (E) and ambient (A) alkalinity treatments. The elevated alkalinity treatment in (a) is further divided into elevated 1 (elevated 1; black squares) and elevated 2 (elevated 2; grey triangles). For elevated 1, total alkalinity was increased on day 1 and for elevated 2, total alkalinity was increased on day 8

There was a marked decrease in NPP rates for the ambient alkalinity treatment and a slight increase for the elevated alkalinity treatment going from week 1 to week 2 (Fig. 3c). Like the light and dark calcification rates, there was no significant difference between the elevated and ambient alkalinity treatments for NPP or NR.

From the combustion data and the $\mathrm{CaCO}_{3}$ to $\mathrm{C}_{\text {org }}$ ratio, it was estimated that, on average, a total of $0.09 \mathrm{~g}$ of $\mathrm{C}_{\text {org }}$ was produced by the Corallina spp. under the elevated alkalinity treatment and $0.07 \mathrm{~g}$ of $\mathrm{C}_{\text {org }}$ was produced by the Corallina spp. under the ambient alkalinity treatment (Table 4). Primary productivity was also estimated using the $\mathrm{CaCO}_{3}$ to $\mathrm{C}_{\text {org }}$ content 
Table 4 Results from $\mathrm{CaCO}_{3}$ and organic carbon $\left(\mathrm{C}_{\mathrm{org}}\right)$ analysis of Corallina spp. samples and primary productivity rates $\left(\mathrm{mg} \mathrm{C} \mathrm{gDW}{ }^{-1} \mathrm{~h}^{-1}\right)$ estimated from these values where $g D W^{-1}$ is the average dry weight of the Corallina spp. samples and $h$ is time in hours. Error $( \pm)$ estimated using error from Meyer et al. (2015)

\begin{tabular}{|c|c|c|c|c|c|c|c|}
\hline \multirow[t]{2}{*}{ Treatment } & \multicolumn{2}{|c|}{$\%$ of total weight } & \multirow{2}{*}{$\begin{array}{l}\text { Ratio } \\
\mathrm{CaCO}_{3}: \mathrm{C}_{\text {org }}\end{array}$} & \multicolumn{2}{|c|}{ Cumulative $\mathrm{CaCO}_{3}$} & \multirow{2}{*}{$\begin{array}{l}\text { Cumulative } \mathrm{C}_{\text {org }} \\
\text { (g) }\end{array}$} & \multirow{2}{*}{$\begin{array}{l}\text { Primary Productivity } \\
\left(\mathrm{mg} \mathrm{C}_{\mathrm{org}} \mathrm{gDW}^{-1} \mathrm{~h}^{-1}\right)\end{array}$} \\
\hline & $\mathrm{C}_{\text {org }}$ & $\mathrm{CaCO}_{3}$ & & $(\mu \mathrm{mol})$ & (g) & & \\
\hline Ambient & 26 & 58 & 0.45 & 1542 & 0.15 & 0.07 & $0.21 \pm 0.06$ \\
\hline Elevated 1 & 24 & 60 & 0.40 & 2306 & 0.23 & 0.09 & $0.31 \pm 0.09$ \\
\hline Elevated 2 & 26 & 59 & 0.44 & 2075 & 0.21 & 0.09 & $0.33 \pm 0.10$ \\
\hline
\end{tabular}

ratio of the Corallina spp. samples. The primary productivity rates for Corallina spp. were $50 \%$ higher for the elevated alkalinity treatments (elevated 1 and elevated 2) compared to that for the ambient alkalinity treatment (Table 4). The calculation of primary productivity was assumed that the rates were equivalent to the measured cumulative alkalinity change and that there was no variation in the ratio of $\mathrm{CaCO}_{3}$ to $\mathrm{C}_{\text {org }}$ content of the Corallina spp. throughout the experiment. However, Meyer et al. (2015) suggest as much as $> \pm 30 \%$ variation in the ratio of inorganic to organic carbon for calcareous algae may be possible. Therefore, this error $( \pm 30 \%)$ has also been taken into account for the primary productivity rates calculated using this ratio (Table 4).

\subsection{Photophysiology}

Corallina spp. showed no significant difference in $\mathrm{rETR}_{\max }, F_{v} / F_{m}, \alpha$, and $E_{k}$ between the elevated and ambient alkalinity treatments (Table 3). There was a positive linear relationship between $F_{v} / F_{m}$ and TA $\left(R^{2}=0.1563, p<0.01\right), \mathrm{rETR}_{\max }$ and temperature $\left(R^{2}=0.09817\right.$, $p<0.05)$, and $\alpha$ and PAR $\left(R^{2}=0.0779, p<0.05\right)$ (Table 4).

Both elevated and ambient alkalinity Corallina spp. $F_{v} / F_{m}$ remained relatively constant throughout the study period, decreasing by $6 \%$ and $11 \%$ from 7 to 27 February respectively (Fig. 4a). Elevated alkalinity Corallina spp. $E_{k}$ also remained relatively constant throughout the study period, only decreasing by $2 \%$ from the 7 to 27 February, whereas ambient alkalinity Corallina spp. $E_{k}$ decreased by $47 \%$ from 7 to 27 February (Fig. $4 b$ ). Corallina spp. rETR $_{\max }$

Table 5 Results from linear regression analysis of (a) Corallina spp. NCR ( $\mu$ mol $\left.\mathrm{CaCO}_{3} \mathrm{gDW}^{-1} \mathrm{~h}^{-1}\right), F_{v} / F_{m}, E_{k}$, $\alpha$, and $\mathrm{rETR}_{\max }$ in relation to TA $\left(\mu \mathrm{Eq} \mathrm{L} \mathrm{L}^{-1}\right), \mathrm{pH}$, temperature $\left({ }^{\circ} \mathrm{C}\right)$, and PAR ( $\mu$ mol photons $\left.\mathrm{m}^{-2} \mathrm{~s}^{-1}\right)$ and (b) Corallina spp. NCR $\left(\mu \mathrm{mol} \mathrm{CaCO}_{3} \mathrm{gDW}^{-1} \mathrm{~h}^{-1}\right.$ ) in relation to Corallina spp. $\mathrm{rETR}_{\max }, \alpha, E_{k}$, and $F_{v} / F_{m}$. Relationship explained by the regression $\left(R^{2}\right)$, overall significance (sig), and number of observations $(N)$. Significant codes: $* p<0.05, * * p<0.01, * * * p<0.001, \mathrm{~ns}=$ not significant

\begin{tabular}{|c|c|c|c|c|c|c|c|c|c|c|c|c|}
\hline \multirow[t]{2}{*}{ a) } & \multicolumn{3}{|l|}{ TA } & \multicolumn{3}{|l|}{$\mathrm{pH}$} & \multicolumn{3}{|c|}{ Temperature } & \multicolumn{3}{|l|}{ PAR } \\
\hline & $R^{2}$ & sig & $N$ & $R^{2}$ & sig & $N$ & $R^{2}$ & sig & $N$ & $R^{2}$ & sig & $N$ \\
\hline $\mathrm{NCR}$ & 0.3998 & $* * *$ & 106 & 0.1141 & $* * *$ & 106 & $2 \times 10^{-5}$ & ns & 106 & 0.05 & $*$ & 83 \\
\hline$F_{v} / F_{m}$ & 0.1563 & $* *$ & 56 & 0.0689 & ns & 56 & 0.05 & $\mathrm{~ns}$ & 56 & 0.01 & ns & 56 \\
\hline$E_{k}$ & 0.0039 & ns & 56 & 0.0039 & ns & 56 & 0.03 & $\mathrm{~ns}$ & 56 & $1.43 \times 10^{-4}$ & ns & 56 \\
\hline $\mathrm{rETR}_{\max }$ & 0.0058 & ns & 56 & 0.0203 & ns & 56 & 0.10 & $*$ & 56 & 0.04 & ns & 56 \\
\hline$\alpha$ & 0.0008 & ns & 56 & 0.0648 & ns & 56 & 0.05 & $\mathrm{~ns}$ & 56 & 0.08 & $*$ & 56 \\
\hline \multirow[t]{2}{*}{ b) } & $\mathrm{rETR}_{\max }$ & & & $\alpha$ & & & $E_{k}$ & & & $F_{v} / F_{m}$ & & \\
\hline & $R^{2}$ & sig & $N$ & $R^{2}$ & sig & $N$ & $R^{2}$ & sig & $N$ & $R^{2}$ & sig & $N$ \\
\hline NCR & 0.0996 & $*$ & 56 & 0.0814 & $*$ & 56 & 0.004 & $\mathrm{~ns}$ & 56 & 0.210 & $* * *$ & 56 \\
\hline
\end{tabular}



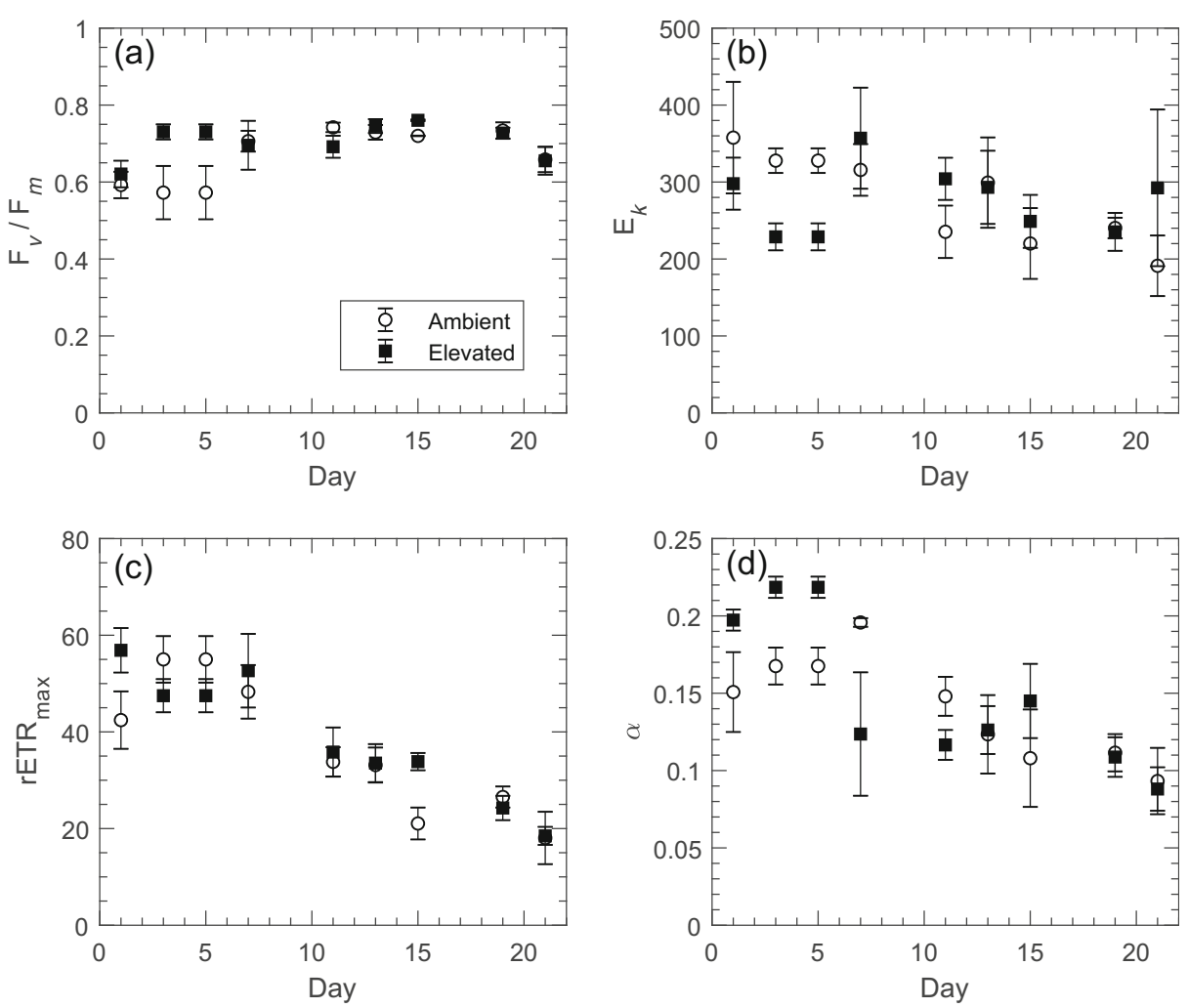

Fig. 4 Average elevated alkalinity (black squares) and ambient alkalinity (empty circles) Corallina spp. $F_{v} / F_{m}$ (a), $E_{k}(\mathbf{b}), \mathrm{rETR}_{\max }(\mathbf{c})$, and $\alpha(\mathbf{d})$ over the study period. Error bars show standard error. All parameters are dimensionless

and $\alpha$ saw similar decreases throughout the study period; elevated alkalinity Corallina spp. $\mathrm{rETR}_{\max }$ and $\alpha$ decreased by $67 \%$ and $55 \%$ respectively, and ambient alkalinity Corallina spp. rETR $_{\max }$ and $\alpha$ decreased by $38 \%$ and $57 \%$ respectively (Fig. $4 \mathrm{c}, \mathrm{d}$ ). There was a positive linear relationship between NCR and both $\operatorname{rETR}_{\max }\left(R^{2}=0.09212, p<0.05\right)$ and $F_{v} / F_{m}\left(R^{2}=\right.$ $0.213, p<0.001$ ) (Table 4).

\section{Discussion}

Results from this study show that increased TA can influence Corallina spp. physiology. Corallina spp. net calcification rate significantly increased by $\sim 60 \%$ and $\mathrm{CaCO}_{3}$ content increased by $\sim 3 \%$ when exposed to elevated alkalinity compared to the ambient alkalinity treatment. This is due to an increase in both light and dark calcification rates under increased TA. However, due to the small sample sizes, there was no significant difference between the alkalinity treatments for light and dark calcification rates. Other, non-statistically significant, physiology changes included Corallina spp. net primary productivity increasing and net respiration rates decreasing when exposed to elevated alkalinity compared to ambient alkalinity. There was no significant difference between the alkalinity treatments for Corallina spp. 
photophysiological parameters. These results have important implications constraining the environmental impact and efficiency of NETs such as increasing ocean alkalinity.

\subsection{Calcification}

The strongest regression relationship for net calcification rates (NCR) was with TA $\left(R^{2}=\right.$ $0.3998, p<0.001)$ suggesting that the higher rates of calcification for the elevated alkalinity treatment were due to the increase in TA. The increase in TA caused calcite $\Omega_{\mathrm{CaCO} 3}$ to increase by $114 \%$ resulting in Corallina spp. NCR to increase by $\sim 60 \%$ and $\mathrm{CaCO}_{3}$ content to increase by $\sim 3 \%$. Higher $\Omega_{\mathrm{CaCO} 3}$ creates more favourable conditions for Corallina spp. to produce $\mathrm{CaCO}_{3}$. This finding is consistent with that of Hofmann et al. (2012a) where C. officinalis growth rate and inorganic carbon content increased by $\sim 50 \%$ and $\sim 3 \%$, respectively, when calcite $\Omega_{\mathrm{CaCO} 3}$ increased by $194 \%$ (due to a decrease in $\mathrm{pCO}_{2}$ ). A similar response was seen for a coral reef flat where the aragonite $\Omega_{\mathrm{CaCO}}$ increased by approximately $50 \%$ (due to increased TA) resulting in an increase of NCR by approximately 7\% (Albright et al. 2016).

Contrary to this, Williamson et al. (2017) found that a $34.2 \%$ increase in calcite $\Omega_{\mathrm{CaCO} 3}$ (despite TA and $\mathrm{HCO}_{3}{ }^{-}$decreasing by $2.4 \%$ and $9.3 \%$ respectively) occurred with a $\sim 65 \%$ decrease in $C$. officinalis light calcification rates. The increase in $\Omega_{\mathrm{CaCO} 3}$ was most likely caused by a decrease in $\mathrm{pCO}_{2}(\sim 28.5 \%)$. This discrepancy between the investigations may be explained by their different methodologies. This study and the investigations by Hofmann et al. (2012a) and Albright et al. (2016) purposely altered the carbonate chemistry compared to Williamson et al. (2017) who did not. Instead, Williamson et al. (2017) investigated the response of $C$. officinalis to a tidal emersion. Williamson et al. (2017) concluded that factors such as temperature and light levels had the strongest influence on $C$. officinalis calcification rates, not the carbonate chemistry. Therefore, in an ex-situ environment where temperature and light levels were held constant, like this study, carbonate chemistry may have more influence over calcification rates.

In-situ light and dark calcification rate (CR) values from Williamson et al. (2017) are summarised and compared to values from this study in Table 6. The in-situ values are from $C$. officinalis in Combe Martin, North Devon, and were sampled during winter when in-situ temperature and PAR were most similar to the temperature and irradiance values of this study.

Table 6 Comparison of Corallina spp. physiology $\left(\mathrm{LCR}=\right.$ light $\mathrm{CR}\left(\mu \mathrm{mol} \mathrm{CaCO} \mathrm{gDW}^{-1} \mathrm{~h}^{-1}\right), \mathrm{DCR}=$ dark CR $\left(\mu \mathrm{mol} \mathrm{CaCO}_{3} \mathrm{gDW}^{-1} \mathrm{~h}^{-1}\right), \mathrm{NPP}\left(\mu \mathrm{mol} \mathrm{DIC} \mathrm{gDW}{ }^{-1} \mathrm{~h}^{-1}\right), \mathrm{NR}\left(\mu \mathrm{mol} \mathrm{DIC} \mathrm{gDW}{ }^{-1} \mathrm{~h}^{-1}\right), \mathrm{rETR}_{\max }, \alpha, E_{k}$, and $F_{v} / F_{m}$ to in-situ winter $C$. officinalis physiology. LCR, DCR, NPP, and NR values are the averages from week 1 and week 2

\begin{tabular}{lllll}
\hline & In-situ & & This study \\
\hline & Max & Min & Elevated & Ambient \\
LCR & $4^{\mathrm{a}}$ & $2^{\mathrm{a}}$ & 12 & 9 \\
DCR & $-0.40^{\mathrm{a}}$ & $-0.25^{\mathrm{a}}$ & 2.29 & -0.01 \\
NPP & $-15^{\mathrm{a}}$ & $-5^{\mathrm{a}}$ & -12 & -6 \\
NR & $5^{\mathrm{a}}$ & $5^{\mathrm{a}}$ & -0.29 & 0.58 \\
$\mathrm{rETR}$ & $120^{\mathrm{b}}$ & $100^{\mathrm{b}}$ & 35 & 36 \\
$\alpha$ & $0.11^{\mathrm{b}}$ & $0.1^{\mathrm{b}}$ & 0.13 & 0.13 \\
$E_{k}$ & $800^{\mathrm{b}}$ & $700^{\mathrm{b}}$ & 287 & 271 \\
$F_{v} / F_{m}$ & $0.3^{\mathrm{b}}$ & $0.2^{\mathrm{b}}$ & 0.68 & 0.69 \\
\hline
\end{tabular}

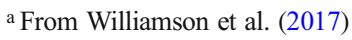

${ }^{b}$ From Williamson et al. (2014) 
Both elevated and ambient alkalinity treatment Corallina spp. light and dark CR were higher compared to the in-situ values. This could be explained by the higher TA values at Dunraven Bay $\left(2694-\mu \mathrm{Eq} \mathrm{L}{ }^{-1}\right)$ compared to North Devon $\left(\sim 2300 \mu \mathrm{Eq} \mathrm{L} \mathrm{L}^{-1}\right)$.

Negative values for calcification rates suggest that instead of calcification, dissolution occurred. Based on previous studies, as summarised in Table 6, this is not unheard of for Corallina spp. and can be explained by an increase in respiration occurring when dark. At the organism level, respiration can generate internal $\mathrm{CO}_{2}$ which lowers internal $\Omega_{\mathrm{CaCO} 3}$ and so can promote $\mathrm{CaCO}_{3}$ dissolution over calcification (Koch et al. 2013). However, dark dissolution (negative values), rather than calcification (positive values) only occurred for the ambient alkalinity treatment in week 1 (Fig. 3b). Dark calcification, rather than dissolution, has previously been documented for Corallina spp. (Williamson et al. 2017; Pentecost 1978; Lee and Carpenter 2001). Whether calcification or dissolution occurs is believed to be strongly related to the rock pool $\Omega_{\mathrm{CaCO} 3}$ (Williamson et al. 2017). In the elevated alkalinity treatments (and ambient alkalinity treatment in week 2), $\Omega_{\mathrm{CaCO} 3}$ was higher, so despite internal $\mathrm{CO}_{2}$ increasing due to respiration, the water $\Omega_{\mathrm{CaCO} 3}$ would have remained high enough to promote calcification rather than dissolution. This is supported by the substantial increases between elevated and ambient alkalinity treatment dark CR for both week 1 and week 2 (Fig. 3b).

\subsection{Photophysiology}

The relatively constant values in $F_{v} / F_{m}$ values suggest little decline in Corallina spp. "health" throughout the experiment. However, there was a reduction in Corallina spp. $\mathrm{rETR}_{\max }, \alpha$, and $E_{k}$ for both the elevated and ambient alkalinity treatments. This suggests less effective photosynthesis at the end of the experiment compared to the start, which may be expected for a multi-week ex-situ experiment.

In-situ photophysiology values from Williamson et al. (2014) were used for comparison to the ex-situ values from this study (Table 6). Williamson et al. (2014) investigated the photophysiology of $C$. officinalis in Combe Martin, North Devon, during winter 2013 (when in-situ temperature and PAR were most similar to the temperature and irradiance values of this study). However, caution should be taken with comparing the photophysiology values as the weather and light conditions would not be exactly the same as those at Dunraven Bay at the time of sampling of this study. For both the elevated and ambient alkalinity treatments, Corallina spp. $\mathrm{rETR}_{\max }$ and $E_{k}$ 's values were lower than in-situ $C$. officinalis $\mathrm{rETR}_{\max }$ and $E_{k}$ values. Further, values of $\alpha$ from this study were slightly higher than the in-stiu values (Table 6) Therefore, $\alpha$ is relatively higher compared to $\mathrm{rETR}_{\max }$ and $E_{k}$, which suggests that the Corallina spp. in this experiment have become acclimated to low light (Perkins et al. 2016). This is likely due to the lower irradiance values $\left(100-200 \mu \mathrm{mol}\right.$ photons $\mathrm{m}^{-2}$ ) of the experimental set-up compared to typical values at Dunraven Bay (150$740 \mu \mathrm{mol}$ photons $\mathrm{m}^{-2}$ ).

There was no statistically significant difference in Corallina spp. $\mathrm{rETR}_{\max }, \alpha, E_{k}$, and $F_{v} / F_{m}$ between the elevated and ambient alkalinity treatments (Table 3). However, there was a significant positive linear relationship between $F_{v} / F_{m}$ and TA $\left(R^{2}=0.1563, p<0.01\right)$ suggesting that increasing TA could have influenced Corallina spp. photosynthetic rates. However, because the Corallina spp. are low-light acclimated (relatively low $\mathrm{rETR}_{\max }$ compared to $\alpha$ ), 
the low-light levels may have had a stronger influence on the photophysiology than alkalinity. This could partly explain why there was no similar increase in $\mathrm{rETR}_{\max }, \alpha$, and $E_{k}$ when TA was increased.

\subsection{Primary productivity and respiration}

Despite there being very little difference in photophysiology between alkalinity treatments, Corallina spp. primary productivity rates (NPP) did increase under elevated alkalinity. However, a note of caution is due here since the chambers were an "open system" and so DIC would have been lost as $\mathrm{CO}_{2}$ through gas-solution diffusion. Therefore, primary productivity was also estimated using the $\mathrm{CaCO}_{3}$ to $\mathrm{C}_{\text {org }}$ content ratio of the Corallina spp. samples. The primary productivity rates estimated this way were approximately ten times larger than the NPP rates estimated using Eq. 2 (once converted to $\mathrm{mg} \mathrm{C} \mathrm{gDW}^{-1} \mathrm{~h}^{-1}$ from $\mu$ mol DIC $\mathrm{gDW}^{-1} \mathrm{~h}^{-1}$ ). This is most likely due to buffering of $\mathrm{CO}_{2}$ from ambient air during the experiment which would mean a smaller change in $\mathrm{pH}$ than what would otherwise occur in a closed system. However, both the primary productivity rates estimated from the $\mathrm{CaCO}_{3}$ to $\mathrm{C}_{\text {org }}$ content ratio and from Eq. 2 were higher for the elevated alkalinity treatment compared to the ambient alkalinity treatment (30\% higher for Eq. 2 calculated NPP rates and 52\% for the $\mathrm{CaCO}_{3}$ to $\mathrm{C}_{\text {org }}$ content ratio calculated NPP rates), therefore, suggesting that increasing TA can increase primary productivity.

Because both calcification and photosynthesis take place in the cell wall, there is a strong relationship between light calcification and photosynthesis. During photosynthesis, internal $\mathrm{CO}_{2}$ decreases causing $\Omega_{\mathrm{CaCO} 3}$ to increase and so promotes calcification (Borowitzka 1982; Koch et al. 2013). This increase in photosynthesis (NPP rather than photophysiology) under elevated alkalinity could partly explain why Corallina spp. net calcification also increased under increased TA. Strong correlations between C. officinalis photosynthesis and calcification have previously been reported by Williamson et al. (2017) and Pentecost (1978) with $R^{2}$ values of 0.65 and 0.886 respectively.

Increasing TA resulted in a greater increase in dark calcification rate $(\sim 200 \%$ increase from ambient to elevated) compared to light calcification (40\% increase from ambient to elevated). Therefore, implying that the increase in Corallina spp. NCR was due to higher $\Omega_{\mathrm{CaCO} 3}$ (from increasing TA) preventing dissolution occurring at night (increased dark calcification) rather than an increase in photosynthesis removing $\mathrm{CO}_{2}$ in the day causing an increase in $\Omega_{\mathrm{CaCO} 3}$ (increased light calcification). Supporting this, in-situ $C$. officinalis primary productivity rates were slightly less than the Corallina spp. primary productivity rates in this study for both the elevated and ambient alkalinity treatments (Table 6). This suggests that Corallina spp. was not fully productive in this experimental set-up despite having higher calcification rates compared to in-situ values.

The near zero and slightly negative values of Corallina spp. respiration rates (NR) are unusual. Respiration produces $\mathrm{CO}_{2}$; therefore, DIC would be expected to increase (Eq. 4) and positive values for NR were expected. The decrease in $\mathrm{pH}$ which occurred after the Corallina spp. were exposed to dark conditions for $6 \mathrm{~h}$ also implies that $\mathrm{CO}_{2}$ was being produced due to respiration. However, because the respiration and primary productivity experiments took place in an open system, they can only give an estimation of NR and 
NPP values and so these results need to be interpreted with caution.

$$
\mathrm{DIC}=\mathrm{CO}_{2}+\mathrm{HCO}_{3}{ }^{2-}+\mathrm{CO}_{3}^{-}
$$

\subsection{Potential for increasing ocean alkalinity as a negative emissions technology and for ocean acidification mitigation}

Increasing TA did not appear to be detrimental for Corallina spp. with respect to calcification or photosynthesis. Based on these findings, solely for Corallina spp. and hence not fully representative of the marine coastal environment, increasing TA (and $\Omega_{\mathrm{CaCO} 3}$ ) could be used to alleviate some of the impacts of ocean acidification. However, if artificially increasing ocean alkalinity (AOA) increases $\Omega_{\mathrm{CaCO} 3}$ to beyond the pre-industrial maximum, there still could be detrimental impacts. For example, Hofmann et al. (2012b) found that increased calcification rates were associated with lower growth rates and lower protein levels which could limit population growth.

A potential downfall to AOA leading to increased calcification rates is the potential increase in oceanic $\mathrm{pCO}_{2}$ which would eventually exchange with the atmosphere and therefore, decrease the efficiency of the oceanic sink for atmospheric $\mathrm{CO}_{2}$. However, this study has shown that for Corallina spp., there was also an increase in primary productivity (which uses up of $\mathrm{CO}_{2}$ ) which suggests that Corallina spp. could still be an overall sink for atmospheric $\mathrm{CO}_{2}$, therefore, suggesting that AOA would still be an effective method of reducing atmospheric $\mathrm{CO}_{2}$ despite an increase in carbonate production. However, only one species was studied, and future investigations should look at the response to different species of marine calcifiers to see if the same results occur.

Biogeochemical modelling studies suggest that using AOA as the sole response to mitigating carbon emissions would increase global surface water calcite $\Omega_{\mathrm{CaCO} 3}$ to between 6 and 7.5 (Paquay and Zeebe 2013; Ferrer-González and Ilyina 2016; Ilyina et al. 2013). This is lower than the increase in $\Omega_{\mathrm{CaCO} 3}$ in this study (calcite $\Omega_{\mathrm{CaCO} 3}=\sim 9$ ). However, modelling studies have suggested that if TA is added to smaller more specific regions (e.g., coastal seas) rather than homogeneously across the whole ocean, the changes in $\Omega_{\mathrm{CaCO} 3}$ could be much greater in these regions. Feng et al. (2017) predict that coastal aragonite $\Omega_{\mathrm{CaCO} 3}$ could increase to between 7 and 16 if TA is added continuously. This is much greater than the increase in this study (aragonite $\Omega_{\mathrm{CaCO} 3}=5.6$ ). Therefore, if localised AOA was to be deployed, there may be global increases in carbonate production similar or even higher than that which occurred in this study. This suggests that the magnitude of the increase in calcification rates would depend on how and where TA was added. For example, localised TA increases may lead to very large changes in $\Omega_{\mathrm{CaCO} 3}$, potentially leading to large increases in carbonate production producing $\mathrm{CO}_{2}$ and so reducing the efficiency of AOA as a NET. This may not be seen if TA is increased homogenously across the open ocean resulting in a reduced increase in $\Omega_{\mathrm{CaCO} 3}$. Therefore, further research into how calcification and primary productivity respond to different TA manipulation scenarios (different $\Omega_{\mathrm{CaCO} 3}$ ) is needed.

\section{Conclusions}

This study set out to investigate the biological and environmental impact of increasing ocean alkalinity as a NET. This investigation has shown that increasing TA did not significantly affect Corallina spp. respiration or photophysiology but did cause a significant increase in calcification rates (NCR increased by $60 \%$ compared to a control) and a substantial, if not 
significant, increase in primary productivity. The increase in carbonate production appears to be due to both increased $\Omega_{\mathrm{CaCO} 3}$ preventing dissolution occurring at night and, to a lesser extent, an increase in photosynthesis leading to an increase in light calcification. The results from this study suggest that artificially increasing ocean alkalinity as a NET may not be detrimental to the marine calcifiers such as Corallina spp. and that it could be used to mitigate against the effects of future ocean acidification. Therefore, increasing ocean alkalinity still appears to be an effective method at removing atmospheric $\mathrm{CO}_{2}$ to achieve negative emissions. To develop a more in-depth understanding of the environmental response to increasing ocean alkalinity as a NET, additional studies are needed to investigate the impact of increasing TA on other marine calcifiers under different TA addition scenarios.

Acknowledgements Dr. Chris Williamson (University of Bristol) is thanked for help with data processing and Professor Stephen Barker (Cardiff University) is thanked for his help throughout the project.

Funding information This study was financially supported by the Natural Environment Research Council (NERC) GW4+ Doctoral Training Partnership, and NERC, the Engineering and Physical Sciences Research Council (EPSRC), Economic \& Social Research Council (ESRC), and the Department for Business, Energy \& Industrial Strategy (BEIS) under grant no. NE/P019730/1.

Publisher's Note Springer Nature remains neutral with regard to jurisdictional claims in published maps and institutional affiliations.

Open Access This article is distributed under the terms of the Creative Commons Attribution 4.0 International License (http://creativecommons.org/licenses/by/4.0/), which permits unrestricted use, distribution, and reproduction in any medium, provided you give appropriate credit to the original author(s) and the source, provide a link to the Creative Commons license, and indicate if changes were made.

\section{References}

Akioka H, Baba M, Masaki T, Johansen WH (1999) Rocky shore turfs dominated by Corallina (Corallinales, Rhodophyta) in northern Japan. Phycol Res 47:199-206. https://doi.org/10.1046/j.1440-1835.1999.00164.x

Albright R, Caldeira L, Hosfelt J, Kwiatkowski L, Mclaren JK et al (2016) Reversal of ocean acidification enhances net coral reef calcification. Nature 531:362-365. https://doi.org/10.1038/nature17155

Andersson AJ, Mackenzie FT, Bates NR (2008) Life on the margin: implications of ocean acidification on Mgcalcite, high latitude and cold-water marine calcifiers. Mar Ecol Prog Ser 373:265-227. https://oi. org/10.3354/meps07639

Archer D (2005) Fate of fossil fuel $\mathrm{CO}_{2}$ in geologic time. J Geophys Res 110(C9). Artn C09s05

Bailey JC, Chapman RL (1998) A phylogenetic study of the Corallinales (Rhodophyta) based on nuclear smallsubunit rRNA gene sequences. J Phycol 34:692-705. https://doi.org/10.1046/j.1529-8817.1998.340692.x

Basso D (2012) Carbonate production by calcareous red algae and global change. Geodiversitas 34(1):13-33. https://doi.org/10.5252/g2012n1a2

Beerling DJ, Leake JR, Long SP, Scholes JD, Ton J, Nelson PN, Bird M, Kantzas E, Taylor LL, Sarkar B, Kelland M, DeLucia E, Kantola I, Müller C, Rau GH, Hansen J (2018) Farming with crops and rocks to address global climate, food and soil security. Nats Plants 4(6):392-392. https://doi.org/10.1038/s41477018-0162-5

Borowitzka MA (1982) Morphological and cytological aspects of algal calcification. Int Rev Cytol 74:127-162. https://doi.org/10.1016/S0074-7696(08)61171-7

Chisholm JRM, Gattuso JP (1991) Validation of the alkalinity anomaly technique for investigating calcification and photosynthesis in coral-reef communities. Limnol Oceanogr 36:1232-1239. https://doi.org/10.4319 /lo.1991.36.6.1232

Chuck A, Tyrrell T, Totterdell IJ, Holligan PM (2005) The oceanic response to carbon emissions over the next century: investigation using three ocean carbon cycle models. Tellus B 57:70-86. https://doi.org/10.1111 /j.1600-0889.2005.00127.x 
Cripps G, Widdicombe S, Spicer JI, Findlay HS (2013) Biological impacts of enhanced alkalinity in Carcinus maenas. Mar Pollut Bull 71(1-2):190-198. https://doi.org/10.1016/j.marpolbul.2013.03.015

Cyronak T, Andersson AJ, Langdon C, Albright R, Bates NR, Caldeira K, Carlton R, Corredor JE, Dunbar RB, Enochs I, Erez J, Eyre BD, Gattuso JP, Gledhill D, Kayanne H, Kline DI, Koweek DA, Lantz C, Lazar B, Manzello D, McMahon A, Meléndez M, Page HN, Santos IR, Schulz KG, Shaw E, Silverman J, Suzuki A, Teneva L, Watanabe A, Yamamoto S (2018) Taking the metabolic pulse of the world's coral reefs. PLoS One 13(1):e0190872. https://doi.org/10.1371/journal.pone.0190872

Dickson AG, Millero FJ (1987) A comparison of the equilibrium constants for the dissociation of carbonic acid in seawater media. Deep Sea Res Part 1 Oceanogr Res Pap 34:1733-1174. https://doi.org/10.1146/annurev. marine.010908.163834

Dickson AG, Sabine CL, Christian J R (Eds) (2007) Guide to best practices for ocean $\mathrm{CO}_{2}$ measurements. Sidney, British Columbia

Doney SC, Fabry VJ, Feely RA, Kleypas JA (2009) Ocean acidification: the other CO2 problem. Annu Rev Mar Sci 1:169-192 0.1146/annurev.marine.010908.163834

Egilsdottir H, Noisette F, Noël LM-LJ, Olafsson J, Martin S (2013) Effects of $p$ CO2 on physiology and skeletal mineralogy in a tidal pool coralline alga Corallina elongate. Mar Biol 160:2103-2112. https://oi. org/10.1007/s00227-012-2090-7

Eilers PHC, Peeters JCH (1988) A model for the relationship between light intensity and the rate of photosynthesis in phytoplankton. Ecol Model 42:199-215. https://doi.org/10.1016/0304-3800(88)90057-9

Feng EY, Koeve W, Keller DP, Oschlies A (2017) Model-based assessment of the $\mathrm{CO}_{2}$ sequestration potential of coastal ocean alkalinization. Earth's Future 5(12):1252-1266. https://doi.org/10.1002/2017ef000659

Ferrer-González M, Ilyina T (2016) Impacts of artificial ocean alkalinization on the carbon cycle and climate in Earth system simulations. Geophys Res Lett 43:6493-6502. https://doi.org/10.1002/2016g1068576

Genty B, Briantais JM, Baker NR (1989) The relationship between the quantum yield of photosynthetic electron transport and quenching of chlorophyll fluorescence. Biochim Biophys Acta 990:87-92. https://oi. org/10.1016/S0304-4165(89)80016-9

Gim B-M, Hong S, Lee J-S, Kim N-H, Kwon E-M, Gil JW, Lim HH, Jeon EC, Khim JS (2018) Potential ecotoxicological effects of elevated bicarbonate ion concentrations on marine organisms. Environ Pollut 241:194-199. https://doi.org/10.1016/j.envpol.2018.05.057

GrapherTM, Golden Software, LLC. Golden, Colorado. www.goldensoftware.com. Accessed 27 July 2018

Hartmann J, West AJ, Renforth P, Köhler P, De La Rocha CL et al (2013) Enhanced chemical weathering as a geoengineering strategy to reduce atmospheric carbon dioxide, supply nutrients, and mitigate ocean acidification. Rev Geophys 51(2):113-149. https://doi.org/10.1002/rog.20004

Harvey LDD (2008) Mitigating the atmospheric $\mathrm{CO}_{2}$ increase and ocean acidification by adding limestone powder to upwelling regions. J Geophys Res 113:C04028. https://doi.org/10.1029/2007jc004373

Henley WJ (1993) Measurement and interpretation of photosynthesis light-response curves in algae in the context of photoinhibition and diel changes. J Phycol 29:729-739. https://doi.org/10.1111/j.00223646.1993.00729.x

Hofmann L, Straub S, Bischof K (2012a) Competition between calcifying and noncalcifying temperate marine macroalgae under elevated $\mathrm{CO}_{2}$ levels. Mar Ecol Prog Ser 464:89-105. https://doi.org/10.3354/meps09892

Hofmann L, Yildiz G, Hanelt D, Bischof K (2012b) Physiological responses of the calcifying Rhodophyta, Corallina officinalis (L.), to future $\mathrm{CO}_{2}$ levels. Mar Biol 159:783-792. https://doi.org/10.1007/s00227-0111854-9

Hönisch B, Hemming NG, Archer D, Siddall M, McManus JF (2009) Atmospheric carbon dioxide concentration across the mid-Pleistocene transition. Science 324:1551-1554. https://doi.org/10.1126/science.1171477

House KZ, House CH, Schrag DP, Aziz MJ (2007) Electrochemical acceleration of chemical weathering as an energetically feasible approach to mitigating anthropogenic climate change. Environ Sci Technol 41:8464 8470. https://doi.org/10.1021/es0701816

Ilyina T, Wolf-Gladrow D, Munhoven G, Heinze C (2013) Assessing the potential of calcium-based artificial ocean alkalinization to mitigate rising atmospheric $\mathrm{CO}_{2}$ and ocean acidification. Geophys Res Lett 40:59095914. https://doi.org/10.1002/2013g1057981

Kheshgi HS (1995) Sequestering atmospheric carbon dioxide by increasing ocean alkalinity. Energy 20:915-922. https://doi.org/10.1016/0360-5442(95)00035-F

Koch M, Bowes G, Ross C, Zhang X-H (2013) Climate change and ocean acidification effects on seagrasses and marine macroalgae. Glob Chang Biol 19:103-132. https://doi.org/10.1111/j.1365-2486.2012.02791.x

Köhler P, Hartmann J, Wolf-Gladrow DA (2010) Geoengineering potential of artificially enhanced silicate weathering of olivine. Proc Natl Acad Sci 107(47):20228-20233. https://doi.org/10.1073/pnas.1000545107

Lee D, Carpenter SJ (2001) Isotopic disequilibrium in marine calcareous algae. Chem Geol 172:307-329. https://doi.org/10.1016/S0009-2541(00)00258-8 
Lord NS, Ridgwell A, Thorne MC, Lunt DJ (2016) An impulse response function for the "long tail" of excess atmospheric $\mathrm{CO}_{2}$ in an Earth system model. Glob Biogeochem Cycles 30:2-17. https://doi.org/10.1002 $/ 2014 \mathrm{gb} 005074$

Martin S, Gattuso J-P (2009) Response of Mediterranean coralline algae to ocean acidification and elevated temperature. Glob Chang Biol 15:2089-2100. https://doi.org/10.1111/j.1365-2486.2009.01874.x

Martin S, Clavier J, Chauvaud L, Thouzeau G (2007) Community metabolism in temperate maerl beds. I. Carbon and carbonate fluxes. Mar Ecol Prog Ser 335:19-29. https://doi.org/10.3354/meps335031

MATLAB (2018) The MathWorks, Inc., Natick, Massachusetts, United States

Mehrbach C, Culberson CH, Hawley JE, Pytkowicz RM (1973) Measurement of the apparent dissociation constants of carbonic acid in seawater at atmospheric pressure. Limnol Oceanogr 18:897-907. https://doi. org/10.4319/lo.1973.18.6.0897

Meyer FW, Vogel N, Teichberg M, Uthicke S, Wild C (2015) The physiological response of two green calcifying algae from the great barrier reef towards high dissolved inorganic and organic carbon (DIC and DOC) availability. PLoS One 10(8):e0133596. https://doi.org/10.1371/journal.pone.0133596

Meysman FJR, Montserrat F (2017) Negative $\mathrm{CO}_{2}$ emissions via enhanced silicate weathering in coastal environments. Biol Lett 13(4):20160905. https://doi.org/10.1098/rsbl.2016.0905

Noisette F, Egilsdottir H, Davoult D, Martin S (2013) Physiological responses of three temperate coralline algae from contrasting habitats to near-future ocean acidification. J Exp Mar Bio Ecol 448:179-187. https://doi. org/10.1016/j.jembe.2013.07.006

Paquay FS, Zeebe RE (2013) Assessing possible consequences of ocean liming on ocean pH, atmospheric CO2 concentration and associated costs. Int J Greenhouse Gas Control 17:183-188. https://doi.org/10.1016/j. ijggc.2013.05.005

Pentecost A (1978) Calcification and photosynthesis in Corallina officinalis L. using $\mathrm{CO}_{2}$ C-14 method. $\mathrm{Br}$ Phycol J 13:383-390. https://doi.org/10.1080/00071617800650431

Perkins RG, Mouget J-L, Lefebvre S, Lavaud J (2006) Light response curve methodology and possible implications in the application of chlorophyll fluorescence to benthic diatoms. Mar Biol 149:703-712. https://doi.org/10.1007/s00227-005-0222-z

Perkins RG, Williamson CJ, Brodie J, Barille L, Launeau P et al (2016) Microspatial variability in community structure and photophysiology of calcified macroalgal microbiomes revealed by coupling of hyperspectral and high-resolution fluorescence imaging. Sci Rep 6:22343. https://doi.org/10.1038/srep22343

Pierrot D, Lewis E, Wallace DWR (2006) MS Excel program developed for CO2 system calculations. ORNL/CDIAC-105a. Carbon Dioxide Information Analysis Center, Oak Ridge National Laboratory, US Department of Energy, Oak Ridge. https://doi.org/10.3334/CDIAC/otg.CO2SYS_XLS_CDIAC105a

Rau GH, Caldeira K (1999) Enhanced carbonate dissolution: a means of sequestering waste CO2 as ocean bicarbonate. Energy Convers Manag 40:1803-1813. https://doi.org/10.1016/S0196-8904(99)00071-0

R Core Team (2013) R: a language and environment for statistical computing. https:/www.R-project.org/. Accessed 5 Feb 2018

Rau GH, Willauer HD, Ren ZJ (2018) The global potential for converting renewable electricity to negative- $\mathrm{CO}_{2}$ emissions hydrogen. Nat Clim Chang 8:621-625. https://doi.org/10.1038/s41558-018-0203-0

Renforth P, Henderson G (2017) Assessing ocean alkalinity for carbon sequestration. Rev Geophys 55(3):636674. https://doi.org/10.1002/2016rg000533

Renforth P, Jenkins BG, Kruger T (2013) Engineering challenges of ocean liming. Energy 60:442-452. https://doi.org/10.1016/j.energy.2013.08.006

Rigopoulos I, Harrison AL, Delimitis A, Ioannou I, Efstathiou AM, Kyratsi T, Oelkers EH (2017) Carbon sequestration via enhanced weathering of peridotites and basalts in seawater. Appl Geochem 91:197-207. https://doi.org/10.1016/j.apgeochem.2017.11.001

Sakshaug E, Bricaud A, Dandonneau Y, Falkowski PG, Kiefer DA, Legendre L, Morel A, Parslow J, Takahashi M (1997) Parameters of photosynthesis: definitions, theory and interpretation of results. J Plankton Res 19: 1637-1670. https://doi.org/10.1093/plankt/19.11.1637

Schreiber U (2004) Pulse-amplitude (PAM) fluorometry and saturation pulse method. In: Papageorgiou, G., Govindjee, (Eds.), Chlorophyll fluorescence: a signature of photosynthesis. Advances in photosynthesis and respiration series. Dordrecht, The Netherlands. https://doi.org/10.1007/978-1-4020-3218-9_11

Schuiling RD, de Boer PL (2010) Coastal spreading of olivine to control atmospheric $\mathrm{CO}_{2}$ concentrations: a critical analysis of viability. Comment: nature and laboratory models are different. Int J Greenhouse Gas Control 4:855-856. https://doi.org/10.1016/j.ijggc.2010.04.012

Smith SV, Key G (1975) Carbon dioxide and metabolism in marine environments. Limnol Oceanogr 20:493495. https://doi.org/10.4319/lo.1975.20.3.0493

United Nations Framework Convention on Climate Change (2015). Adoption of the Paris Agreement. Report No. FCCC/CP/2015/L.9/Rev.1. http://unfccc.int/resource/docs/2015/cop21/eng/109r01.pdf. Accessed 27 Aug 2018 
Walsh DA, Zaikova E, Hallam SJ (2009) Large volume (20L+) filtration of coastal seawater samples. J Vis Exp (28):1161. https://doi.org/10.3791/1161

Williamson CJ, Brodie J, Goss B, Yallop M, Lee S, Perkins R (2014) Corallina and Ellisolandia (Corallinales, Rhodophyta) photophysiology over daylight tidal emersion: interactions with irradiance, temperature and carbonate chemistry. Mar Biol 161:2051-2068. https://doi.org/10.1007/s00227-014-2485-8

Williamson CJ, Perkins R, Voller M, Yallop M, Brodie J (2017) The regulation of coralline algal physiology, an in-situ study of Corallina officinalis (Corallinales, Rhodophyta). Biogeosci 14(19):4485-4498. https://doi. org/10.5194/bg-14-4485-2017

Wolf-Gladrow DA, Zeebe RE, Klaas C, Körtzinger A, Dickson AG (2007) Total alkalinity: the explicit conservative expression and its application to biogeochemical processes. Mar Chem 106(1-2):287-300. https://doi.org/10.1016/j.marchem.2007.01.006 